\title{
Grafts of ovaries in males and females of Pleurodeles waltl (urodele amphibia): evidence of a long-term tolerance of allografts; application following a space biology experiment
}

\author{
C Dournon ${ }^{1 *}$, C Aimar ${ }^{2}$, A Bautz ${ }^{1}$, A Ropars $^{1}$, C Houillon ${ }^{1}$ \\ I UPRES EA 2401 Génétique et interactions cellulaires en reproduction, \\ Laboratory of experimental biology-immunology, Henri-Poincaré University, \\ Nancy-1, BP 239, 54506 Vandouvre-lès-Nancy cedex; \\ ${ }^{2}$ Laboratory of comparative immunology, Pierre-et-Marie-Curie University, \\ 75252 Paris cedex 05, France
}

(Received 13 June 1997; accepted 18 November 1997)

\begin{abstract}
Summary - Ovary grafts were investigated in the salamander Pleurodeles using juveniles and adults as donors and hosts. Ovaries were provided by standard or histo-compatible strains and by standard females which had been submitted to a space flight. Laparotomy of the hosts was used to control viability of grafts. Entire juvenile ovaries transplanted into castrated juvenile females or males were tolerated and developed. Ovarian parts of adult females, which contained a majority of oogonies, could also be tolerated by juvenile animals. In addition, ovarian parts supported a better recovery and differentiation than parts that mainly included mature oocytes. About 24 months after the ovary grafts, some hosts (genetical females or males and standard or spatialized females) crossed with standard males provided progenies originating from oocytes of the grafted ovaries. The protocols applied offer a new range of potentialities, adapted to various experimental purposes such as life science research in space or sex differentiation studies.
\end{abstract}

ovary grafting / sex reversal / space flight / urodele amphibia

Résumé - Greffes d'ovaires chez les mâles et les femelles de Pleurodeles waltl (amphibien urodèle) : mise en évidence de la tolérance à ces allogreffes; application à l'issue d'une expérience réalisée lors d'un vol spatial. Des greffes d'ovaire ont été réalisées chez Pleurodeles (amphibien urodèle) à partir d'animaux juvéniles et adultes utilisés comme donneurs ou receveurs castrés. Les ovaires proviennent de lignées standard ou histocompatibles mais aussi de femelles ayant séjourné

\footnotetext{
* Correspondence and reprints
}

Tel: (33) 03839123 15; fax: (33) 03839124 46; e-mail: dournon@ scbiol.u-nancy.fr 
dans l'espace. La prise des greffons a été contrôlée par laparotomie. Des ovaires juvéniles entiers ont été tolérés par des mâles et des femelles juvéniles préalablement castrés. Des fractions d'ovaire adulte qui contiennent une majorité d'ovogonies peuvent elles aussi être tolérées par des juvéniles. Deux ans après la greffe, certains receveurs (mâles ou femelles génétiques et femelles normales ou spatialisées) accouplés avec des mâles standard ont donné des descendances issues des ovocytes émis par les ovaires greffés. Ce protocole offre de nouvelles possibilités expérimentales, adaptées à l'étude de la différenciation et de l'inversion sexuelle ou à des contraintes de reproduction liées aux conditions d'expérimentation dans l'espace.

\section{greffe d'ovaire / inversion sexuelle / expérience spatiale / amphibien urodèle}

\section{INTRODUCTION}

Organ or tissue grafts constitute a technique used in experimental biology, mostly in mammals, avians and amphibia. In amphibia, grafts are preferentially realized on embryos because their immune system is not yet functional. Grafts exchanged between embryos of the same species (intraspecific combinations) are tolerated and develop in a regular manner, irrespective of their orthotopic or heterotopic location (Humphrey, 1928; Mikamo and Witschi, 1963). Analysing the relationships between grafted and host tissues in heterospecific combinations, Houillon (1972, 1973, 1975) showed that such combinations did not exclude an immunitary tolerance.

In amphibia, various experimental models clearly demonstrate that the viability of intra or heterospecific tissue combinations is insured if tissue associations are realized using animals at an embryonic stage of development. Results of implantation of adult tissues on adult recipients are not so predictable because of the presence of the efficient immune system of the host at the time of the graft. The immune system becomes functional at the end of the larval period for most amphibia and after about 3 months of development for the axolotl (Ambystoma mexicanum), a neotenic and paedogenic animal. It can be expected that the active immune system of an adult host provokes a grafted tissue rejection (Houillon, 1967).
In fact, occurrence of skin graft rejection exceeds $75 \%$ for adult Pleurodeles standard populations. Moreover, the time of a graft rejection depends on the number of previous grafts supported by the recipient animal, and is about 2 months after the grafting for the first set and 2 weeks for the following sets (Tournefier et al, 1969, 1970). Comparatively, the occurrence of reciprocal tolerance to skin grafts is about $40 \%$ on animals of the same sibling or on chimaeras (Goujon, 1974). In contrast, absence of reciprocal graft rejection is the general rule for animals which are thymectomized (Charlemagne and Houillon, 1968; Fache and Charlemagne, 1975) or cloned using the technique of nuclear transplantation (Aimar, 1971, 1972), or for experimental twins, or animals belonging to strains selected for their histocompatibility (Charlemagne and Tournefier, 1974).

Most of the information about tissue graftings on adult animals is provided by skin transfer experiments. Grafts of other differentiated tissues provided by adult animals mostly remains to be investigated. It is worth noting that the immunoreactivity (rejection or tolerance) of ovary allografts has never been documented in amphibia. The aim of this work was to question the fate of ovary allografts on postmetamorphic Pleurodeles waltl. Due to the combination of different germinal and somatic cells, the ovarian tissues could develop an antigenicity different from that of somatic tissues. 
As the behaviour of a graft could also depend on the age and sex of the recipient animals, protocols of ovary grafting were applied using juvenile or adult Pleurodeles from both sexes, as both recipients and donors. For comparison, standard or histocompatible strains were used. The ovary of an adult exhibits an antero-posterior anatomical differentiation. The posterior part of the ovary is mainly the site of proliferative oogonies, whereas growing and mature oocytes are located in the middle and anterior parts. Taking account of this feature, the grafts were performed using entire or selected ovary parts.

In addition, a particular interest of gonad grafting experiments is relevant to the fact that, in amphibia, a treatment by oestrogen steroids provokes the reversion of the phenotypic sex (Gallien, 1950, 1954; Chardard et al, 1995). It could be hypothesized that an ovary grafting induces some morphological or physiological alterations of the host genital tract, a side-effect due to the oestrogen. In this finding, previously castrated hosts were used and the differentiation of their genital tract was carefully examined.

The protocol of gonad grafting has found an application in an experiment devoted to the effects of radiations on the amphibia germinal cells. Genetic abnormalities such as chromosomal deletions, translocations and DNA alterations, which affect both somatic and germ cells, can be experimentally induced by radiations (Gurdon, 1960; Horneck et al, 1984; Kadhim et al, 1992; Cadet et al, 1993; Sabatier et al, 1993). In amphibia, X-rays induce chromosomal deletions and/or translocations (Jaylet and Vacquier, 1967; Labrousse, 1969; Jaylet, 1971; Lacroix and Loones, 1971) and UV irradiation of the vegetative pole of eggs destroys the initial germ cells in anuran (Bounoure, 1937). Alpha and gamma radiations, UV rays, electrons, protons and heavy ions are detected in space (Reitz, 1993). In order to analyse their effects on germ cells, $P$ walt females have been submitted to a space flight. An ovary graft is used in such an experiment as a suppletive way to obtain offspring of the spatialized females. The meaning of this process is explained herein.

The protocol of the ovary grafts of standard and spatialized females was described and the experimental results were analysed and discussed.

\section{MATERIAL AND METHODS}

\section{Strains}

Pleurodeles waltl is an urodele amphibia species originating from Spain, Portugal and Morocco (Rudolf et al, 1996). The animals used belong to histo-compatible (Charlemagne and Tournefier, 1974) or various standard strains raised in the laboratory. Metamorphosis of larvae occurs 3 months after egg fertilization and the Pleurodeles reaches sexual maturity at about 15 months old. The differentiation of the genital tract of the amphibia is well known and the effects of oestrogens on the gonadal differentiation and sexual reversion is widely documented (Gallien, 1973). All the animals were reared in the laboratory at room temperature $\left(20 \pm 2{ }^{\circ} \mathrm{C}\right)$. In this study, French guidelines for the care and use of laboratory amphibia were followed.

\section{Preliminary procedures and anaesthesia of animals}

The animals were deprived of food for 8 days before any surgical operation (castration, ovary excision and ovary grafting, laparotomy). A good healthy animal may tolerate up to 5-6 weeks of fasting. All the surgical operations were performed under general anaesthesia (3\% benzocaine in $95 \%$ ethanol diluted by $1 \%$ in water before use). To minimize the risks of contamination the animals were gently washed with household soap. The soap was washed of with running water. 


\section{Castration of recipient animals}

To be used as recipients for ovary transfers, juvenile animals, males or females, and adult females were castrated (figs 1 and 2). Skin and abdominal muscles were incised on both sides of the animals along the lateral line system using a stereoscopic microscope. The mesovariums or the mesorchiums were cut off using PascheffWolff scissors and the ovaries or testes were then removed. The castrated animals were kept ready.

\section{Ovary transfers and development of the ovary grafts}

Ovaries that were to be grafted were excised according to the above protocol for castration. They were gently washed in Steinberg medium (Steinberg, 1957) in order to eliminate lysed cells and coagulated blood cells, then stored in the same medium for a maximum of $30 \mathrm{~min}$ before use.

According to the various experiment procedures, whole ovaries or parts of ovaries were grafted into the body cavity of castrated recipient animals (figs 2 and 3). Whole ovaries were provided by juvenile animals. Parts of ovaries were excised from the anterior, middle or posterior region of ovaries of 2-years-old females. Transferred ovarian tissues were about $2.5 \mathrm{~cm}$ in size for the juvenile and $2 \mathrm{~cm}$ in size for the parts of adult ovaries. In order to improve the success of the grafting and the healing of the wound, the ovarian tissue was placed close to the severed mesovarium or mesorchium at the same location as that of the formerly excised ovary or testis (orthotopic position). Thus, the grafted ovary was firmly bound between the gut and the gut mesenter. The wound was then stitched. Full recovery of the animals occurred after 2 weeks during which feed was progressively restored. The success of the graft was assessed by the rapid recovery of irrigation in the mesovarium and the ovary, followed by the progressive increase in the size of the ovarian tissues. At the time of optimal development of the grafts, about 2 years after grafting, recipient animals were mated with standard males and their spawnings analysed.

\section{Laparotomy}

Development of the grafted ovaries can be checked by laparotomy of the recipient animals. Because of the anatomical disorders generated by this procedure (adhesion between tissues), only one laparotomy could be performed on each animal.

\section{Space flight history}

The Russian satellite Cosmos 2229 (Bion 10) was launched from Plessetsk on 29 December 1992. Fifteen standard females, 2 years old, were housed on board (in-board females) in a life-support unit and a same number in a ground refer-

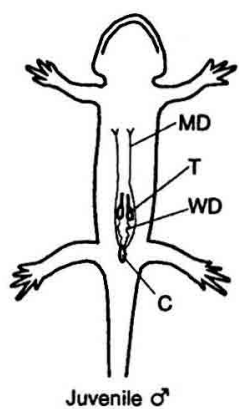

Juvenile ox

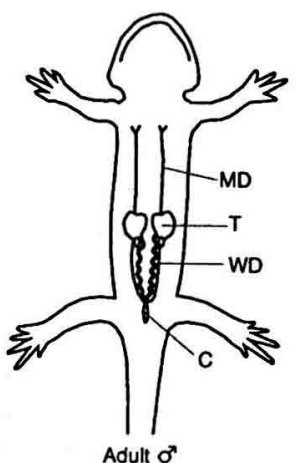

Adult $0^{7}$
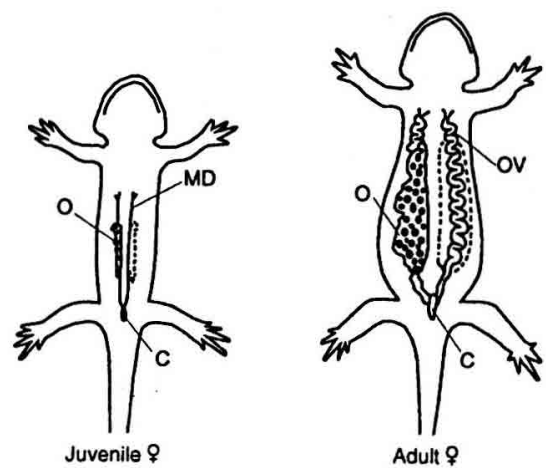

Fig 1. Schematic representation of the genital tracts of juvenile and adult of Pleurodeles walt (ventral views). C: cloacal orifice; MD: müllerian duct; O: ovary; Ov: oviduct; T: testis; WD: wolffian duct. 


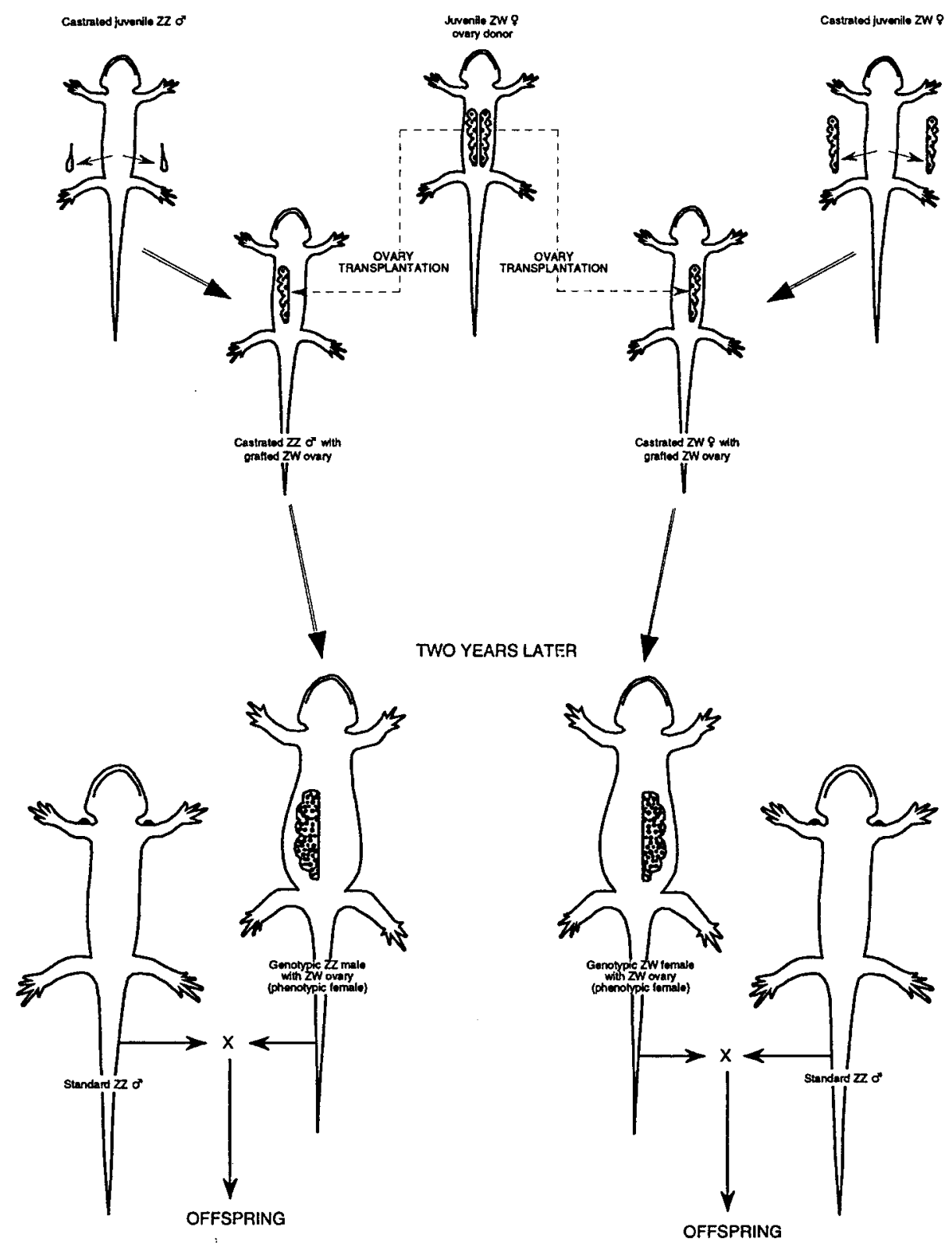

Fig 2. Protocols for functional ovary grafts (ventral views). 


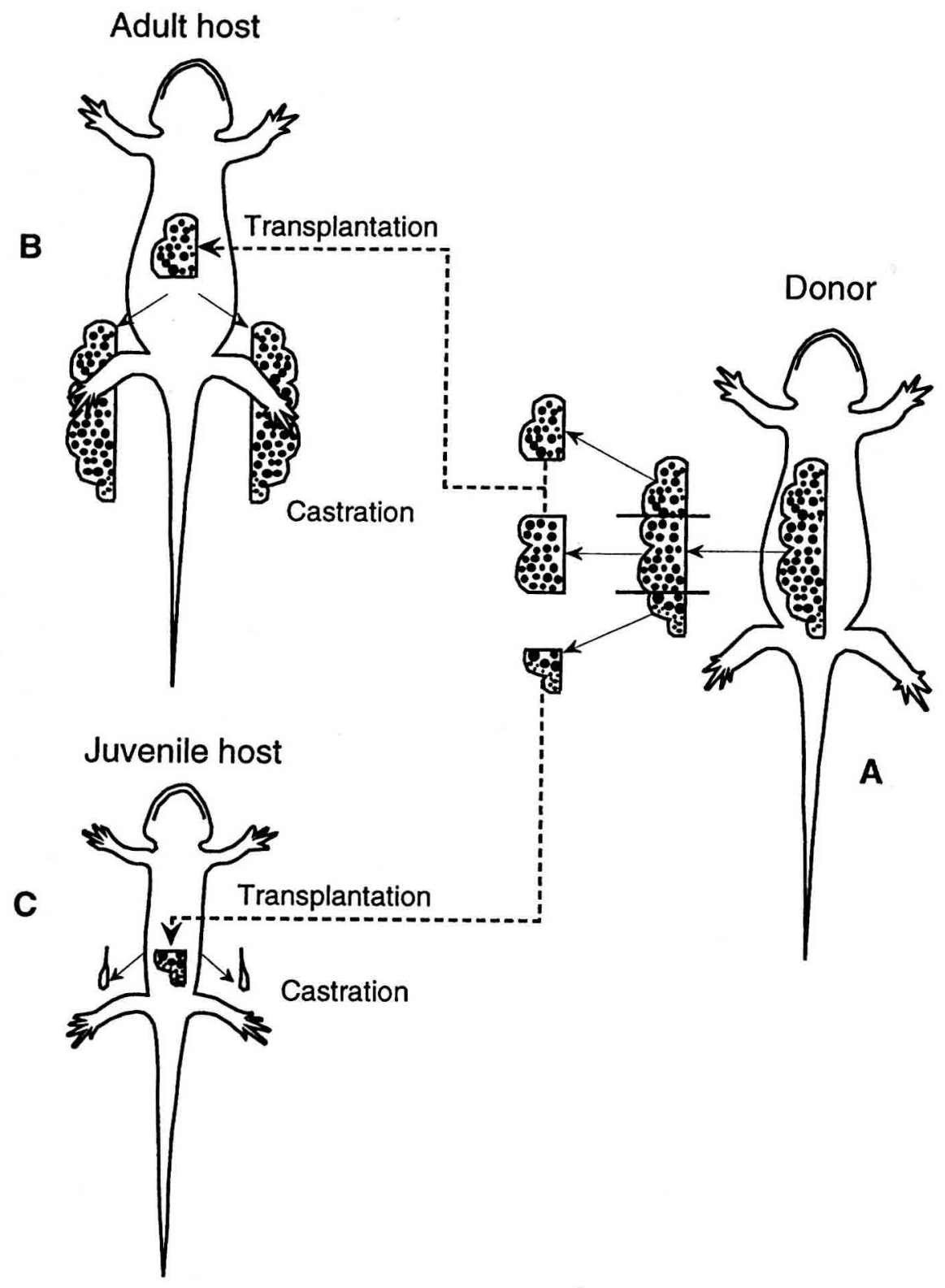

Fig 3. Ovary graft: the various procedure applied to Bion 10 experiments (ventral views). A: In-board female or ground control female; $\mathbf{B}$ : castrated adult female used as recipient of an anterior or central part of ovary; $\mathbf{C}$ : castrated juvenile male used as recipient of a posterior part of ovary. 
ence unit (ground control females, 2 years old). The flight was planned for a duration of 14 days. Starting from day 10 , the temperature on board increased progressively within about $30 \mathrm{~h}$ from 22 to $32^{\circ} \mathrm{C}$ and the flight was cut short. Bion 10 landed on 10 January 1993, after a 12-day flight. Ten hours after the satellite landing only five onboard females out of 15 were still alive. In contrast, all the ground-control females were in good health. The ambient temperature in the ground control unit was $2^{\circ} \mathrm{C}$ lower than that aboard Bion 10 . Following the protocol specified by the Russian teams, all the surviving embarked females were killed $10-12 \mathrm{~h}$ after landing in order to provide organ sampling. Thus, in accordance with our scientific purposes, ovaries of in-board females were removed and re-implanted in recipient animals with a maximum delay of $30 \mathrm{~min}$ (fig 3). The recipient animals were juvenile standard males, 4 months old and adult standard females, 2 years old.

\section{RESULTS}

\section{Grafts of juvenile ovary on juvenile castrated animals}

The ovary transfers were performed on postmetamorphic animals 4-10 months old. Both male and female castrated recipient animals belonging to histo-compatible and standard strains were used. In order to detect possible alteration of the host genital tract differentiation, only one whole juvenile ovary was grafted on each recipient animal.

\section{Grafts of entire juvenile ovary in juvenile females}

\section{Fate of the grafted ovary (table I)}

Transfers $(N=10)$ of ovaries were made between females of a histo-compatible strain. All the grafts $(100 \%)$ recovered irrigation and the grafted tissues increased in size progressively, attesting the long-term tolerance of the grafts. When performed on standard females issued from different offspring, $87 \%$ of grafts $(N=30)$ developed the same pattern as in the histo-compatible strain. Young oocytes in the grafted ovaries of the two batches achieved their cytodifferentiation and became full grown within 2 years.

\section{Fate of the host genital tract}

The genital tract of Pleurodeles juvenile animals consists of two wolffian ducts and two müllerian ducts. These latter differentiated into oviducts in adult females. In our experiments, the castrated females bearing a grafted ovary, exhibited when adults oviducts as differentiated as in the control females. Moreover, Pleurodeles females, as in mammals, exhibit an anatomical discontinuity between the ovaries and the genital tract (oviducts). This discontinuity remains present in the hosts (fig 1). It allowed the artificial system grafted ovary/genital tract to be physiologically functional.

Table I. Grafts of ovaries performed between juvenile donors and hosts in Pleurodeles waltl.

\begin{tabular}{lccccc}
\hline & \multicolumn{2}{c}{$\begin{array}{c}\text { Juvenile ovary } \\
\text { Srafted into juvenile females }\end{array}$} & & \multicolumn{2}{c}{$\begin{array}{c}\text { Juvenile ovary } \\
\text { grafted into juvenile males }\end{array}$} \\
\cline { 2 - 3 } \cline { 5 - 6 } Strains & Histo-compatible & Standard & & Histo-compatible & Standard \\
\hline No of grafts & 10 & 30 & & 12 & 25 \\
Success & $10(100 \%)$ & $26(87 \%)$ & & $12(100 \%)$ & $21(84 \%)$ \\
No of matings & 8 & 12 & & 3 & 9 \\
Layings & $6(75 \%)$ & $9(75 \%)$ & & $3(100 \%)$ & $5(56 \%)$ \\
\hline
\end{tabular}


Progeny of the ovary grafted females

When the recipient animals became adults they exhibited an enlarged abdomen on the side where the ovary part was grafted. Eight females issued from the histo-compatible strain and 12 issued from the standard strain, selected on this morphological criterion, were mated with histo-compatible and standard males, respectively. Offspring were obtained for six of the eight females of the histo-compatible strain (75\%) and for nine of the 12 females of the standard strain $(75 \%)$. The number of eggs varied according to the females in a range between 150 and 400 , with no significant difference between the strains; all eggs developed in normal embryos in the same proportions, about $90 \%$, as control eggs.

\section{Grafts of entire juvenile ovary in juvenile males}

\section{Fate of the grafted ovary (table I)}

All the transfers $(N=12)$ were successful and the grafted ovaries became fully developed when males were issued from a histocompatible strain. In contrast, only $84 \%$ of the grafts $(N=25)$ differentiated in a natural way and were therefore tolerated by the recipient males, when these were issued from standard offspring.

\section{Fate of the host genital tracts}

In all of the hosts the grafted ovaries induced the host juvenile males to differentiate into phenotypic females. These males, transformed into neofemales, exhibited, on the abdominal side where the ovary was grafted, a complete and functional genital tract, ie, ovary (the grafted one) and oviduct (fig 1). Moreover, oviduct, on the side deprived of gonad, and cloacal glands also developed. The müllerian duct close to the grafted ovary was often more developed than the opposite duct.
Three neofemales issued from the histocompatible strain and nine issued from the standard stain were mated with histo-compatible and standard males, respectively. The three females (100\%) of the histo-compatible strain and five on the nine females (56\%) of the standard strain provided offspring. The volume of the spawning ranged from 100 to 300 and the fertilized eggs developed normally.

It can be observed that the difference between the number of progenies issued from histo-compatible and standard strains were not significant because of the small number of parents and the single criterion chosen for their selection. For the same reasons, the difference between the number of eggs laid by histo-compatible and standard animals or by grafted females and grafted males, respectively, were also not significant (table I).

\section{Grafts of a piece of adult ovary on juvenile or adult castrated animals (Bion 10 experiment)}

In this protocol, only a part (anterior, middle or posterior) of the ovaries of the in-board adult females and of the ground controls were grafted into juvenile animals 4 months old or into adult castrated animals 2 years old.

\section{Grafts of a piece of adult ovary in juvenile males}

Donors: in-board females (fig 3, table II)

Of the five castrated juvenile males grafted with posterior parts of ovaries, two died 2 weeks after grafting. One year later, the genital tracts of the three surviving recipient males were observed using laparotomy. Two (40\%) of them exhibited well-developed oocytes and two müllerian ducts and were transformed into phenotypic females. The third recipient animal maintained a male 
phenotype. Necrosis of the tissues at the location of the implantation was observed. This looked like a feature of a slow rejection of the grafted ovary. Twenty-seven months after the grafting, one of the two recipient animals spontaneously laid 300 non-fertilized oocytes, and 30 months after the graft both the animals died. When dissected, the animal exhibited one voluminous mature oocyte-containing ovary, which although implanted on the left side of the abdomen, had invaded the right side. The other animal presented, on its left side, one ovary of a reduced size but containing mature oocytes. In each animal the two müllerian ducts were fully developed.

\section{Donors: ground control adult females}

Of the five castrated juvenile males grafted with the posterior part of ovaries excised from adult females, two animals died during the first month following the grafting. The three other ones $(60 \%)$ exhibited, within a few months, a typical female morphologic phenotype. Laparotomy of these animals was performed 1 year after the ovary graft. The grafted ovaries and the muillerian ducts looked well developed attesting to the success of the graftings and to the complete sex reversion of the recipient males. These three animals died 21, 25 and 29 months after the grafting. Dissections revealed a complete differentiation of their two müllerian ducts and the presence of voluminous and welldeveloped ovaries located on the left side of the abdomen.

\section{Grafts of a piece of adult ovary in adult females}

\section{Donors: in board females (fig 3, table II)}

Castrated adult females were grafted with an anterior or middle part of the ovaries of the in board adult females. Nine of the ten hosts died during the first 2 weeks following the graftings. The last one (10\%) still alive was of a female morphologic type. It exhibited a healthy grafted ovary and two welldeveloped mullerian ducts. Thirty-one months after the gonad grafting, at the end of the breeding season, this female was mated with a standard male and spawned about 50 eggs. These eggs were non-fertilized because no spermatophore was laid down by the male. This functional neofemale died 5 months later. Dissection showed one large ovary, including mature oocytes, located on the left side of the abdomen. The two mullerian ducts were developed.

Table II. Grafts of ovaries performed after the Bion-10 space flight.

\begin{tabular}{lccccc}
\hline & \multicolumn{2}{c}{$\begin{array}{c}\text { Grafts into juvenile } \\
\text { castrated males of posterior } \\
\text { part of ovary from: }\end{array}$} & & \multicolumn{2}{c}{$\begin{array}{c}\text { Grafts into adult } \\
\text { castrated females of anterior } \\
\text { and central part of ovary from: }\end{array}$} \\
\cline { 2 - 3 } $\begin{array}{l}\text { Donors } \\
\text { of grafts }\end{array}$ & $\begin{array}{c}\text { In-board } \\
\text { females }\end{array}$ & $\begin{array}{c}\text { Ground control } \\
\text { females }\end{array}$ & & $\begin{array}{c}\text { In-board } \\
\text { females }\end{array}$ & $\begin{array}{c}\text { Ground control } \\
\text { females }\end{array}$ \\
\hline $\begin{array}{l}\text { No of donors } \\
\text { Grafted animals }\end{array}$ & 5 & 5 & 5 & 5 & 5 \\
$\begin{array}{l}\text { Surviving animals } \\
\text { Animals with }\end{array}$ & 3 & 3 & & 10 & 5 \\
successful graft & $2(40 \%)$ & $3(60 \%)$ & & $1(10 \%)$ & $0(0 \%)$ \\
\hline
\end{tabular}

In-board females: females submitted to 12 days microgravity and radiations during Bion 10 space flight; ground control females: females submitted to the same rearing conditions but in laboratory (see Material and methods). 
Donors: ground control adult females

Castrated adult females $(N=5)$ were grafted with an anterior or a middle part of the ovaries of ground control adult females. All died within the first weeks following ovary transfers.

To summarize the data, the graft of anterior or middle parts of adult ovaries caused, in most cases, the death of the recipient animal. In contrast, the posterior ovary part could develop if grafted on juvenile animals.

\section{DISCUSSION}

The success of the graft of a somatic tissue such as skin depends on the histo-compatibility level between hosts and donors. In this work, the modalities of allografts of the ovary were investigated. Comparatively to skin grafts, the development of ovary grafts also depends on various genetic factors, but apparently in a more acute way. Moreover an ovary, by itself, can modify the sexual phenotype of the host.

The relationship between viability of the graft and the immunity pattern of both donor and host was documented in our work. Ovary development in standard or histocompatible combinations using juvenile animals was 85 and $100 \%$, respectively. Rejection or tolerance are not a function of the sex of the juvenile hosts. In standard combinations, grafts of posterior parts of the adult ovary in juvenile recipient males were successful in $60 \%$ of the cases. In contrast, the grafts were successful in less than $10 \%$ for anterior or central parts of adult ovaries implanted into adult female hosts. Thus, tolerance to a grafted ovary revealed a dependence on the lineage of the host and on the age of the hosts. Such results contrast with current data on skin graft experiments. Embryonic ectoderm or larval skin are tolerated when grafted on embryos or larvae, respectively, because the immunoreactive system is inactive (Houillon, 1967; Goujon, 1974). In contrast, adult tissues such as skin, in most of the cases (about $75 \%$ ), are rejected when grafted on standard animals (Tournefier et al, 1970; Goujon, 1974). Therefore, as shown in standard strains, the tolerance of ovarian tissues of the Pleurodeles seems to be higher than that of the skin.

These results showing the low level of antigenicity of the ovarian tissue could be explained by the difference in the immunological pattern between ovarian tissues and others adult tissues. In the axolotl, antigens of class I are expressed in the skin and in other somatic organs, whereas in the ovarian tissue their expression is low, so the immunogenicity of the ovary is depleted (Tournefier, pers comm). The same phenomena could occur in Pleurodeles since the immunological patterns of the urodele seem to be very similar.

In comparison to juvenile animals, achievement of organogenesis in the host does not act as a limiting or inhibitory factor on the development of grafted gonads since in Pleurodeles, the transfer of an ovary could be performed both on juvenile and adult animals. Thus, the development of the grafted ovary can be assimilated to the typical regenerative process in amphibia. Such results were relevant to the reproductive physiology of the amphibia. In the adult female, a new set of oogenesis takes place after each seasonal egg spawning. In addition, the growth of the grafted ovaries appeared also to depend on a regulative process since the size of the grafted ovaries were always consistent with the size of the host animal. As a general rule, grafting preferentially requires juvenile animals as hosts. The present experiments support this since more than $85 \%$ of graftings on juvenile animals proved successful. However, it was observed that, on such hosts, the development rate of grafts on a juvenile or an adult donor were quite similar. 
In addition our experiments indicate the correlation between age of grafts and their survival. The grafted parts of adult ovaries or entire juvenile ovaries were roughly of the same size. However, grafts of juvenile ovaries were more successful (84-87\%) than the transfer of parts of adult ovaries $(60 \%$ in the best case). It can be hypothesized that this difference is due to the presence or absence of vitellogenic oocytes in the grafted ovar parts. In fact, the grafts of the posterior part of an adult or juvenile ovary, which contained many oogonies and growing oocytes, were successful in more than $60 \%$ of the cases. In contrast, grafts of anterior and middle parts of ovaries, which contained many vitellogenic oocytes, failed to develop ( $0 \%$ success, table II). Vitellogenic oocytes, which show a very active metabolism, rapidly degenerate in absence of nutrients, a situation which could occur in ovary grafts before blood irrigation recovery. Alternatively, an acute rejection of the grafts cannot be excluded.

In the experiments dealing with the spatial flight, no difference in the behaviour of grafts issued from standard or ground females and in-board females was observed. However, failure of ovary graftings can be a consequence of the drastic elevation of the temperature during the flight. It is evidence for the assumption that high temperature provokes necrosis of full-grown oocytes, but damages to a lesser extent oogonies or young oocytes. In vitro long-term maintenance of full-grown oocytes at a temperature higher than $20^{\circ} \mathrm{C}$ rapidly reduces their survival. In our experiments, the necrosis of ovary grafts was probably the major cause of the death of the recipient animals.

The eggs of two animals (genetic male and female) hosts of parts of spatialized ovary and mated with standard males were not fertilized. This result expresses the success of the grafts but does not provide any information on the developmental ability of spatialized oocytes.
A particular feature of this work was to investigate the incidence of the grafted ovaries on the sex of juvenile hosts. Castrated host juvenile males differentiated in females exhibiting well-developed müllerian ducts and an ovary. These neofemales were able to lay fertilized eggs, the development of which was normal. This unexpected result demonstrates the fact that a grafted ovary, independently of its juvenile or adult state of development, had the ability to induce the sex reversion of the host. In Pleurodeles species as in other amphibia species, sex reversion can be obtained using steroid hormones (Gallien, 1950; Chardard et al, 1995) or by applying a thermal treatment (Dournon et al, 1990). As shown here, it can also be provoked by a physiologically active female gonad, ie, secreting endogenous oestrogens. The sex reversion of the males is due to the fact that, in this amphibia species, the male is the neutral sex. Absence or presence of female hormones leads to male and female differentiation, respectively (Gallien, 1973). In addition, müllerian ducts, which are vestigial in a male, were developed attesting their permanent inductibility by steroid hormones.

Our experiments show that if transferred into a host animal an entire or a single part of an ovary can restore a developed ovary. These results illustrated two points. On the one hand, in contrast to most somatic tissues, such as skin, the molecules of class I were probably less expressed in ovarian tissues, which have a low antigenicity and can be tolerated by a host if grafted. Further investigations on the antigenicity of amphibia ovaries need to be performed. On the other hand, grafted ovaries can induce a functional sex reversion of a castrated host. Consequently, mating of host animals (genetic females or males) with standard males provides progeny issued from oocytes of the grafted ovaries. The obtention of fertilized eggs demonstrated the success of the technique. In conclusion, the protocols of transfers of gonad that we have applied offer 
a new range of experimental investigations adapted to various purposes in life sciences research as sex differentiation studies.

\section{ACKNOWLEDGMENTS}

We would like to thank SL Znoiko, N Bruslinskaja and V Mitashov from the Institute of Developmental Biology of Academy of Sciences in Moscow for their friendly help. We also thank $\mathrm{C}$ Causse, C Tankosic and K Briot from the Laboratory of experimental Biology-Immunology in Nancy. We thank L Serova (IBMP, Moscow) for the coordination of the Bion 10 biological experiments. This work was supported by the MST of the Ministère de l'éducation, de la recherche et de la technologie and by the French space agency (CNES).

\section{REFERENCES}

Aimar C (1971) Etude par homogreffes cutanées, des réactions immunitaires chez des individus isogéniques obtenus par transplantation nucléaire chez le triton Pleurodeles waltiii. C R Acad Sci Paris 272, 2221-2224

Aimar C (1972) Analyse par la greffe nucléaire des propriétés morphogénétiques des noyaux embryonnaires chez Pleurodeles waltlii Michah. Application à l'étude de la gémellarité expérimentale. Ann Embryol Morph 5, 5-42

Bounoure L (1937) Le sort de la lignée germinale chez la Grenouille rousse après action des rayons ultraviolets sur le pôle inférieur de l'oeuf. CR Acad Sci Paris 204, 1837-1839

Cadet J, Berger M, Incardona MF, Odin F, Polverelli M, Sabatier L, Nevzgodina L (1993) Effects of cosmic radiation on the DNA of biological samples. Fifth European Symposium on Life Sciences Research in Space, ESA-CNES, Abstracts RAD-006

Chardard D, Desvages G, Pieau C, Dournon C (1995) Aromatase activity in larval gonads of Pleurodeles waltl (urodele amphibia) during normal differentiation and during reversal by thermal treatment effect. Gen Comp Endocrinol 99, 100-107

Charlemagne J, Houillon C (1968) Effets de la thymectomie larvaire chez l'Amphibien Urodèle Pleurodeles waltiii Michah. Production à l'état adulte d'une tolérance aux homogreffes cutanées. $C R$ Acad Sci Paris 267, 253-256

Charlemagne J, Tournefier A (1974) Obtention of histocompatible strains in the urodele Pleurodeles waltlii
Michah. (Salamandridae). J Immunogenet 1, 125129

Dournon C, Houillon C, Pieau C (1990) Temperature reversal in Amphibia and Reptiles. Int $J$ Dev Biol $34,81-92$

Fache B, Charlemagne J (1975) Influence on allograft rejection of thymectomy at different stages of larval development in urodele amphibian. Eur $J$ Immunol 5, 155-157

Gallien L (1950) Inversion du sexe (féminisation) chez l'Urodèle Pleurodeles waltlii Michah. traité par le benzoate d'oestradiol. C R Acad Sci, Paris 231, 919-920

Gallien L (1954) Inversion expérimentale du sexe sous l'action des hormones sexuelles chez le Triton Pleurodeles waltlii Michah. Analyse des conséquences génétiques. Bull Biol Fr et Belg 88, 1-51

Gallien L (1973) In: Différenciation et organogenèse sexuelle des métazoaires. Masson et Cie Editors, Paris

Goujon P (1974) Induction de la tolérance aux allogreffes de peau dans les chimères de l'Amphibien Urodèle, Pleurodeles waltlii Michah. J Embryol exp Morph 32, 805-818

Gurdon JB (1960) The effects of ultraviolet irradiation on uncleaved eggs of Xenopus laevis. Quart $J$ Micr Sci 101, 299-312

Horneck G, Bücker H, Reitz G, Requardt H, Dose K, Martens KD, Mennigmann HD, Weber P (1984) Microorganisms in the space environment. Science $225,226-228$

Houillon C (1967) Greffes embryonnaires de peau entre Ambystoma mexicanum Shaw, Pleurodeles waltii Michah et Triturus alpestris Laur Phénomène de tolérance et de rejet. $C R$ Acad Sci Paris 264, 834-837

Houillon C (1972) Tolérance des greffes ovariennes entre espèces différentes chez les Amphibiens Urodèles; conséquences sur l'émission de pontes hétérologues. C R Acad Sci Paris, série D 274, 2790-2793

Houillon C (1973) Greffes de gonades embryonnaires entre les Amphibiens Urodèles Pleurodeles waltlii Michah et Ambystoma mexicanum Shaw; conséquences sur l'émission de pontes hétérologues. $C$ R Acad Sci Paris, série D 277, 2245-2248

Houillon C (1975) Evolution des xénogreffes de gonades embryonnaires et de gonades d'Ambystoma mexicanum Shaw, transplantées sur Triturus alpestris Laur. C R Acad Sci Paris, série D 281, 171-174

Humphrey RR (1928) Sex differentiation in gonads developed from transplants of the intermediate mesoderm of Amblystoma mexicanum. Biol Bull 55, 317-339

Jaylet A (1971) Création d'une lignée homozygote pour une translocation réciproque chez l'Amphibien Urodèle Pleurodeles waltiti. Chromosoma 34, 383-423 
Jaylet A, Vacquier C (1967) Accidents chromosomiques obtenus à l'état hétérozygote dans la descendance viable de mâles irradiés, chez le triton Pleurodeles waltiii Michah. Cytogenetics 6, 390401

Kadhim MA, Mac Donald DA, Goodhead DT, Lorimore SA, Marsden SJ, Wright EG (1992) Transmission of chromosomal instability after plutonium a-particule irradiation. Nature 355, 738-740

Labrousse M (1969) Aberrations chromosomiques induites et différenciation embryonnaire chez les Amphibiens. Ann Embr Morph suppl 1, 199-210

Lacroix JC, Loones MT (1971) Fragmentations par les rayons $\mathrm{X}$ de l'organisateur d'une différenciation de chromosomes en écouvillon (lampbrush) chez Pleurodeles waltli. Chromosoma 36, 112-118

Mikamo K, Witschi E (1963) Functional sex reversal in genetic females of Xenopus laevis induced by implanted testis. Genetics 48, 1411-1421

Reitz G (1993) Radiation environment in the stratosphere. Radiation Protection Dosimetry 48, 5-20

Rudolf E, Dorazi R, Chesnel A, Durand D, Bautz A, Dournon C (1996) Pleurodeles walt and Pleurodeles poireti: correlations between their iberic or north-african origin and genes $B$ or $\beta$ of peptidase-1, a sex-linked enzyme. Bull Soc Zool Fr 121 (1), $21-29$

Sabatier L, Fedorenko B, Hoffschir F, Flüry-Herard A, Ricoul M , Martins L, Reillandou M, Gerasimenko V, Dutrillaux B (1993) Radiation-induced chromosomal damages during space missions. Fifth European Symposium on Life Sciences Research in Space, ESA-CNES, Abstracts RAD-0-04

Steinberg M (1957) A non-nutrient medium for culturing amphibian embryonic tissues. In: Carnegie Institution of Washington Year Book 56, 347

Tournefier A, Charlemagne J, Houillon C (1969) Evolution des homogreffes cutanées chez l'Amphibien Urodèle Pleurodeles waltlii Michah: Réponses immunitaires primaires et secondaires. $C R$ Acad Sci Paris 268, 1456-1459

Tournefier A, Charlemagne J, Houillon C (1970) Réponses immunitaires aux homogreffes cutanées et absence d'histocompatibilité liée au sexe chez Triturus alpestris Laur. C R Acad Sci Paris 270 , 1057-1060 